\title{
JUSTICIABILITY, FEDERALISM, AND THE ADMINISTRATIVE STATE
}

\author{
Zachary D. Clopton†
}

Article III provides that the judicial power of the United States extends to certain justiciable cases and controversies. So if a plaintiff bringing a federal claim lacks constitutional standing or her dispute is moot under Article III, then a federal court should dismiss. But this dismissal need not end the story. This Article suggests a simple, forward-looking reading of case-or-controversy dismissals: they should be understood as invitations to legislators to consider other pathways for adjudication. A case dismissed for lack of standing, for mootness, or for requesting an advisory opinion might be a candidate for resolution in a state court or administrative agency. And although the Supreme Court has frequently policed the delegation of the "judicial power of the United States," legislative delegations of non-justiciable claims should not transgress those limits. Instead, case-or-controversy dismissals imply that non-Article III options are permissible.

This formulation is more than a doctrinal trick. It has normative consequences across a range of dimensions. For one thing, this approach reinvigorates the separation-of-powers purposes of justiciability doctrine by turning our attention from judges to legislators. When courts seemingly use justiciability to curtail private enforcement or access to justice, we could re-interpret the results as revealing a legislative failure to authorize non-Article III options. More affirmatively, caseor-controversy dismissals could be focal points for political pressure in favor of more rigorous enforcement of important laws that the federal executive may be shirking. Further, consistent with "new new federalist" accounts, this Article suggests another avenue for federal-state interactivity in the development and enforcement of federal law. This too is of added salience given that private and state enforcement may become even more significant in light of the current occupants of the federal executive branch.

$\dagger$ Associate Professor of Law, Cornell Law School. Thank you to Kevin Clermont, Michael Dorf, Heather Elliott, Tara Leigh Grove, F. Andrew Hessick, Richard Re, Martin Redish, Allan Trammell, Chief Judge Diane P. Wood, and the participants in the Loyola Constitutional Law Colloquium for helpful discussions in preparation of this Article. 
INTRODUCTION ................................ 1432

I. ARTICLE III ...................... 1437

A. Cases and Controversies.............. 1438

B. Case-or-Controversy Dismissals ......... 1442

C. The Judicial Power of the United States ...... 1448

II. Non-ARTICLE III LIMITS . . . . . . . . . . . . . . . 1453

III. APPLicATIONS, SMALL AND LARGE . . . . . . . . . . . 1457

A. Writ Small: Spokeo v. Robins ............ 1457

B. Writ Small: Campbell-Ewald Co. v. Gomez.... 1461

C. Writ Large: General Statutes .............. 1463

D. Connections and Consequences........... 1465

CONCLUSION ......................... 1467

\section{INTRODUCTION}

Article III tells us that the judicial power of the United States extends to certain justiciable cases and controversies. ${ }^{1}$ So if a plaintiff bringing a federal claim lacks constitutional standing or her dispute is moot under Article III, then the federal court should dismiss. ${ }^{2}$ But this dismissal need not end the story. ${ }^{3}$ This Article suggests a simple, forward-looking reading of case-or-controversy dismissals: they should be understood as invitations to legislators to consider other pathways for adjudication. A case dismissed for lack of standing, for mootness, or for requesting an advisory opinion may be a candidate for resolution in a state court, an administrative agency, or a legislative tribunal-and that choice is for legislators, not judges. ${ }^{4}$

None of this should be earthshattering. After all, it derives from just a couple sentences of the Constitution. ${ }^{5}$ Yet it runs counter to much of the rhetoric that surrounds Article III jurisprudence. Critics have referred to justiciability doctrine as a "pointless constraint on courts,"6 as "an insupportable judicial

\footnotetext{
1 U.S. CONST. art. III, § 2.

2 See infra subpart I.A.

3 This Article uses the term "dismissal" loosely in two respects. First, sometimes the "dismissal" will be a remand order-cases removed to federal court when there is no federal subject-matter jurisdiction should be remanded to state court. See 28 U.S.C. § 1441 (2018). Second, when the decision has precedential effect, it might operate as a potential invitation to the class of cases for which it has an effect.

4 Bringing together state courts, administrative agencies, and legislative tribunals is consistent with-but does not depend on-Justice Brandeis's commentary on the judicial power in Crowell v. Benson, 285 U.S. 22 (1932) (dissenting).

5 See U.S. ConST. art. III, §§ 1-2.

6 Jonathan R. Siegel, A Theory of Justiciability, 86 TEx. L. REV. 73, 75 (2007).
} 
contraction of the legislative power," 7 and, straightforwardly, as "making it more difficult to implement federal laws." 8 Critics present doomsday scenarios in which important laws governing the environment, consumer protection, and civil rights will go unenforced, 9 and in particular that "private enforcement" of federal law will be neutered. ${ }^{10}$

Such concerns run up to the present day. In 2016, the Supreme Court decided two private-enforcement cases raising issues under Article III: Spokeo, Inc. v. Robins (standing) ${ }^{11}$ and Campbell-Ewald Co. v. Gomez (mootness). ${ }^{12}$ Prior to the death of Justice Scalia, one critic characterized these cases as asking "whether the conservative wing of the Roberts Court will respect our Constitution's guarantee of access to courts or subvert it, leaving Americans without legal recourse when corporations violate federal rights." 13 And although an eightmember Court declined to issue far-reaching holdings, ${ }^{14}$ Donald Trump's appointments to the Supreme Court may reinvigorate these concerns. ${ }^{15}$

While I may share many of the critics' normative priors (and many of their interpretations of Article III), the rhetoric about federal rights is overheated because it is too focused on the federal courts. If we treat Article III dismissals as reflecting the separation of powers-as the Supreme Court tells us we should ${ }^{16}$ - then concerns about under-enforcement should be directed at legislators too. Federal and state legislatures can provide "legal recourse" outside of Article III courts. And although the Supreme Court has frequently policed the delegation of the "judicial Power of the United States," legislative delegations of non-justiciable claims should not transgress

7 Richard J. Pierce, Jr., Lujan v. Defenders of Wildlife: Standing as a Judicially Imposed Limit on Legislative Power, 42 DUKE L.J. 1170, 1170-71 (1993).

8 Robert A. Schapiro, Toward a Theory of Interactive Federalism, 91 IowA L. REv. 243, 303 (2005).

9 See, e.g., supra notes 6-8 and accompanying text; infra notes 13-14, 50-51, 95-97 and accompanying text.

10 See infra note 49 and accompanying text ("private enforcement").

11136 S. Ct. 1540 (2016). See infra subpart III.A.

12136 S. Ct. 663 (2016). See infra subpart III.B.

13 David Gans, No Day in Court: Big Business's Attack on Access to Courts, BALKINIZATION (Oct. 9, 2015), http://balkin.blogspot.com/2015/10/no-day-incourt-big-businesss-attack-on.html [https://perma.cc/2NC6-26T3].

14 Despite the modesty of the Spokeo holding, one critic observed its contribution to standing law "seems to be serving no purpose other than to constitutionalize a deregulatory agenda." Felix T. Wu, How Privacy Distorted Standing Law, 66 DEPAUL L. REV. 439, 440 (2017).

15 See infra notes $23 \& 25$ (identifying vehicles to reconsider these issues).

16 See infra Part I. 
those limits. ${ }^{17}$ An Article III dismissal cuts out federal courts but also leaves open non-Article III options that respect judicial power limits.

This formulation is more than a doctrinal trick or a suggestion that critics of the Supreme Court should speak more precisely. It also maps out an institutional strategy for preserving important federal rights. First, imagine a President and a Supreme Court hostile to regulation and enforcement, and a Congress gridlocked or otherwise inactive. In this scenario, progressive states might look to their courts for opportunities to encourage enforcement of those rights that the federal executive is ignoring and the federal courts are retrenching. Next, imagine that four years later the federal political branches become more amenable to regulation and enforcement, but an entrenched Supreme Court with life-tenured justices is holding fast. In this scenario, a Congress intent on restoring enforcement baselines might see state courts and administrative agencies as a means to avoid the obstacles created by the federal courts. These two accounts depend on a reading of Article III that has escaped sustained scholarly attention.

Fleshing out this vision, this Article proceeds as follows. The first step is to look at Article III itself: what does the caseor-controversy requirement entail, and how does it interact with the Constitution's vesting of the judicial power in the federal courts. ${ }^{18}$ This discussion precipitates the simple reading of Article III mentioned above-that is, that case-or-controversy dismissals invite legislative action. ${ }^{19}$ This Article next looks outside of Article III for potential limits on the legislative responses that such dismissals invite. ${ }^{20}$ The Constitution certainly places some limits on these options, though they derive from sources other than Article III. In addition, institutional design considerations should shape the potential legislative choice between state-court and administrative resolution of non-Article III disputes.

This Article then applies the dismissal-as-invitation thesis, beginning with the two aforementioned cases decided by the Supreme Court in 2016. First, in Spokeo, Inc. $v$. Robins, ${ }^{21}$ the Court asked whether Congress may create the injury that pro-

17 See U.S. Const. art. III, § 1; infra Part I.

18 This Article is agnostic on the scope of the case-or-controversy requirement itself. I assume that such a requirement exists, and then ask what should be done with claims that fall outside of it.

19 See infra Part I.

20 See infra Part II.

21 See infra subpart III.A. 
vides the basis for federal-court standing in a Fair Credit Reporting Act (FCRA) case. ${ }^{22}$ The Spokeo decision was measured, but it indicated some appetite to curtail congressionally created standing. ${ }^{23}$ Consistent with this Article's thesis, were a court to conclude that Congress cannot create the necessary standing, the result would not be an end to private enforcement of the FCRA but instead an invitation for administrative or state-court resolution of FCRA claims without fear of offending the dignity of the federal courts.

Second, in Campbell-Ewald Co. v. Gomez, ${ }^{24}$ the Court considered whether an offer of judgment that moots the claim of a named plaintiff in a class action also moots the claims of the rest of the class. Although the Court declined to find mootness on these facts, it left open other possibilities to undercut private enforcement, and the Chief Justice's dissenting opinion suggested that there was some enthusiasm for further restricting the justiciability of federal class actions. ${ }^{25}$ Again, consistent with this Article's thesis, judicial decisions finding class actions to be moot would be an invitation for administrative or state-court resolution of these disputes.

Finally, this Article considers options for Congress and state legislatures to create general statutes providing for nonArticle III review of non-justiciable federal claims. ${ }^{26}$ This Article explores not only how legislatures could do so, but why they might. This approach is particularly significant when some states (and eventually federal legislators) may be more interested in regulation and enforcement than the President and the Supreme Court.

The conclusions of this Article connect with two significant strains in recent legal scholarship. First, there has been increasing attention on private enforcement as a tool of federal

22 See 15 U.S.C. § 1681 (1970).

23 See Spokeo, Inc. v. Robins, 136 S. Ct. 1540, 1553 (2016). Since Spokeo, the courts of appeals have continued to give the Supreme Court opportunities to take up this question. See, e.g., Attias v. Carefirst, Inc., 865 F.3d 620, 630 (D.C. Cir. 2017), cert denied, 138 S. Ct. 981 (2018) (holding that the risk of identity theft was an injury that satisfied Article III); Syed v. M-I, LLC, 853 F.3d 492, 507 (9th Cir. 2017), cert. denied, 138 S. Ct. 447 (2017) (holding that an informational injury under the FCRA satisfied Article III). See also infra note 183.

24136 S. Ct. 663 (2016). See infra subpart III.B.

25 Here too, the next opportunity to test these issues may come soon. See, e.g., Petition for Writ of Certiorari, Leyse v. Lifetime Entm't Servs., 138 S. Ct. 637 (2018) (No. 17-162) (seeking certiorari to determine whether a defendant's deposit of an offer of judgment renders a case moot). See also infra note 207.

26 See infra subpart III.C. C $f$. Heather Elliott, Congress's Inability to Solve Standing Problems, 91 B.U. L. REV. 159, 205 (2011) (minimizing Congress's options for expanding standing). 
(and state) policy. ${ }^{27}$ Particular attention has been paid to the ways that the federal courts have impeded private-enforcement efforts, including through increased scrutiny on Article III's requirements. By reorienting the focus away from federal courts, this Article minimizes the supposedly negative effects of Article III doctrine for private enforcement. In addition, this Article's recognition of state options interacting with federal standards aligns with the "new new federalist" emphasis on federal-state opportunities. ${ }^{28}$ This Article emphasizes those opportunities as they relate to private litigation and enforcement, rather than the lawmaking focus that dominates that literature. In the context of private enforcement, federalism presents interesting potential for state implementation around national focal points. ${ }^{29}$ This connection of private enforcement and federalism is especially important as the Trump administration is unlikely to be a major source of public enforcement across a range of important issues - though, of course, private enforcement and federalism transcend any one presidential administration.

Before diving in, one brief caveat is in order. This Article does not address non-justiciable suits against federal defendants. Most prominently, this means that it excludes challenges to the constitutionality of federal statutes. Decisions like Clinton $v$. City of New York $^{30}$ and INS v. Chadha ${ }^{31}$ suggest that it would be impermissible to give an administrative or legislative tribunal the ability to alter statutes outside of the normal lawmaking process, and decisions like Cooper $v$. Aaron ${ }^{32}$ reject state nullification of federal law. Those decisions would be among the "non-Article III limits" addressed below, ${ }^{33}$ but because they implicate an important class of cases in its entirety, I mention them separately here. This Article also excludes suits against other federal defendants, which may raise special

27 See infra notes 49-50, 95-97 and accompanying text (discussing private enforcement).

28 See, e.g., Heather K. Gerken, Federalism as the New Nationalism: An Overview, 123 YALE L.J. 1889, 1890 (2014) (providing an overview of the "nationalist school of federalism"); Symposium, Federalism as the New Nationalism, 123 YALE L.J. 1888 (2014) (same).

29 See infra subpart III.C.

30524 U.S. 417 (1998).

31462 U.S. 919 (1983).

32358 U.S. 1 (1958).

33 See infra Part II. 
federalism and separation-of-powers issues beyond the scope of this project. ${ }^{34}$

In sum, the goal of this project is to reinvigorate the separation-of-powers mission of Article III, and perhaps to import a federalism dimension as well. This means that case-or-controversy dismissals should be properly treated not as defeats for legislative goals but as invitations for legislative creativity. And it means that those parties interested in vigorous enforcement of federal law should not be overly distracted by fights about federal-court access (or federal-executive policy) to the exclusion of alternatives that derive from the principles of federalism and the separation of powers. ${ }^{35}$ Importantly, this Article does not endorse the Supreme Court's recent decisions tightening standing or other justiciability doctrines-instead, it suggests that those decisions are not the end of the story. ${ }^{36}$

ARTICLE III

For present purposes, Article III contains two important substantive commands. Section 1 provides that "[t]he judicial Power of the United States, shall be vested in one supreme Court, and in such inferior Courts as the Congress may from time to time ordain and establish." 37 Section 2 further develops this command by stating that the judicial power shall extend to certain cases or controversies. ${ }^{38}$ The federal courts

34 These federal-defendant claims seem to be subject to resolution in administrative or legislative tribunals, and many of them would be acceptable candidates for state-court resolution as well. But because those conclusions would entail more detailed discussion of separation-of-powers and federalism doctrine, I exclude those cases from this Article's reach.

35 Of course, this conclusion has a political dimension-it depends on legislators responding to some of these invitations. Acknowledging that those responses may not always be forthcoming, I address these concerns with respect to federal and state legislators separately.

36 For example, this Article looks at the Court's current conception of Article III rather than the alternative, historical account offered in James E. Pfander \& Daniel D. Birk, Article III Judicial Power, the Adverse-Party Requirement, and NonContentious Jurisdiction, 124 YALE L.J. 1346 (2015).

37 U.S. CONST. art. III, § 1.

38 U.S. CONST. art. III, § 2 ("The judicial Power shall extend to all Cases, in Law and Equity, arising under this Constitution, the Laws of the United States, and Treaties made, or which shall be made, under their Authority; to all Cases affecting Ambassadors, other public Ministers and Consuls; to all Cases of admiralty and maritime Jurisdiction; to Controversies to which the United States will be a Party; to Controversies between two or more States; between a State and Citizens of another State; between Citizens of different States; between Citizens of the same State claiming Lands under Grants of different States, and between a State, or the Citizens thereof, and foreign States, Citizens or Subjects."). 
have principally understood these commands as reflecting the Framers' concerns with the separation of powers. ${ }^{39}$

This Part puts these two commands together. Subpart A briefly surveys the operation of the case-or-controversy requirement in federal courts. Subpart B reads the case-or-controversy requirement to suggest that Congress has the power to provide for resolution of disputes that are not quite cases or controversies through various alternative channels. Subpart C then pivots back to the text of Article III and asks whether its vesting clause places any limits on those alternative channels. Taken together, these provisions establish the central contention of this Article: Article III invites Congress to provide for the resolution of certain federal claims outside of the federal courts.

\section{A. Cases and Controversies}

In order for the federal courts to take jurisdiction, they must identify a "case" or "controversy" within the heads of jurisdiction in Article III. ${ }^{40}$ In applying these requirements, the federal courts have fashioned various doctrines to weed out non-justiciable claims.

Perhaps the most debated such requirement is "standing." 41 Modern federal standing doctrine has three elements: an injury in fact, which is both concrete and particularized, and actual or imminent; a causal connection such that the injury is fairly traceable to the challenged action; and a likelihood of redressability by a favorable decision. ${ }^{42}$ Standing thus attempts to ensure that the parties match the subject matter of the dispute. ${ }^{43}$ The Supreme Court has been emphatic about

\footnotetext{
39 See infra subparts I.A and I.C.

40 U.S. CONST. art. III, § 2 (quoted in relevant part supra note 38 ).

41 See generally Heather Elliott, The Functions of Standing, 61 STAN L. REV. 459 (2008) (discussing the functions and failures of the standing doctrine); William A. Fletcher, The Structure of Standing, 98 YALE L.J. 221 (1988) (proposing a new structure of standing law focused on the merits of plaintiff's claim); F. Andrew Hessick, Standing, Injury in Fact, and Private Rights, 93 CORNELl L. REv. 275 (2008) (arguing the Supreme Court's injury-in-fact requirement in private rights cases undermines separation of powers); Gene R. Nichol, Jr., Justice Scalia, Standing, and Public Law Litigation, 42 DuKE L.J. 1141 (1993) (describing Justice Scalia's role in the development of standing public law litigation); Cass R. Sunstein, What's Standing After Lujan? Of Citizen Suits, "Injuries," and Article III, 91 MiCH. L. REV. 163 (1992) (evaluating standing doctrine after the Supreme Court's decision in Lujan $v$. Defenders of Wildlife).

42 See, e.g., Lujan v. Defs. of Wildlife, 504 U.S. 555, 560 (1992) (outlining the elements of Article III standing).

43 As this description suggests, decisions on standing are seemingly caseand party-specific, but it is conceivable that some arguments on standing have
} 
the basis of standing: "the law of Art. III standing is built on a single basic idea-the idea of separation of powers." 44

I should pause for a moment to elaborate this connection to the separation of powers, which has shifted meanings in the Supreme Court's justiciability jurisprudence. On the one hand, in the Lujan decision, the Court suggested that standing doctrine stops Congress from encroaching on the executive's duty to take care that the laws are enforced. ${ }^{45}$ But in cases before and after Lujan-including in Spokeo ${ }^{46}$ — the Supreme Court confirmed the more orthodox view of standing's relationship to separation of powers, i.e., that it manifests separationof-powers constraints on federal courts. ${ }^{47}$ Indeed, even Lujan's author Justice Scalia adopted this court-constraining view of standing law in his opinion in Steel Co. v. Citizens for a Better Environment. ${ }^{48}$

the practical effect of rendering a class of cases non-justiciable in general. See, e.g., Zachary Clopton, Emoluments and Justiciability, TAKE CARE (June 26, 2017), https://takecareblog.com/blog/emoluments-and-justiciability [https:// perma.cc/YT4P-4CRF].

44 Allen v. Wright, 468 U.S. 737, 752 (1984). See generally Cass R. Sunstein, Standing and the Privatization of Public Law, 88 ColuM. L. REV. 1432, 1459-61 (1988) (describing the role of the separation of powers in the development of the standing doctrine for private-law disputes).

45504 U.S. at 577 ("If the concrete injury requirement has the separation-ofpowers significance we have always said, the answer must be obvious: To permit Congress to convert the undifferentiated public interest in executive officers' compliance with the law into an 'individual right' vindicable in the courts is to permit Congress to transfer from the President to the courts the Chief Executive's most important constitutional duty, to 'take Care that the Laws be faithfully executed.'"); see also Fletcher, supra note 41, at 233 ("Where standing to enforce statutorily established duties is at issue, an 'injury in fact' requirement operates as a limitation on the power normally exercised by a legislative body."); Tara Leigh Grove, Standing as an Article II Nondelegation Doctrine, 11 U. PA. J. CONST. L. 781, 785 (2009) (offering an Article II theory of standing) Michael C. Dorf, Supreme Court Requires “Concrete" Injury for Standing, VERDICT (May 18, 2016), https://ver dict.justia.com/2016/05/18/supreme-court-requires-concrete-injury-standing [https://perma.cc/886F-AET6] ("Congressional authorization of private lawsuits to compel enforcement could . . . be seen as an effort to shift power from the president to Congress. Accordingly, prior standing cases expressly invoke separation of powers.").

46 Spokeo, Inc. v. Robins, 136 S. Ct. 1540 (2016). Spokeo cited a footnote from Raines $v$. Byrd, which is appended to the phrase: "In the light of this overriding and time-honored concern about keeping the Judiciary's power within its proper constitutional sphere . ..." 521 U.S. 811, 820 (1997). The two other cases cited by Spokeo are equally clear that Article III is about constraining the courts. See Summers v. Earth Island Inst., 555 U.S. 488 (2009); Gladstone, Realtors v. Vill. of Bellwood, 441 U.S. 91 (1979).

47 See Spokeo, 136 S. Ct. at 1547 (collecting cases).

48523 U.S. 83, 102 n.4 (1998) ("Our opinion is not motivated ... by the more specific separation-of-powers concern that this citizen's suit somehow interferes with the Executive's power to take Care that the Laws be faithfully executed. The courts must stay within their constitutionally prescribed sphere of action, 
In any event, in recent years, the federal courts have narrowed standing doctrine for private claims, raising the ire particularly of those worried about the private enforcement of federal law. Across a range of issues, Congress has empowered private attorneys general to enforce federal statutory rights. ${ }^{49}$ Scholars have called out the Supreme Court's standing decisions as impediments to private enforcement generally, 50 while environmental and consumer advocates have expressed particular concern about standing in private suits on those subjects. ${ }^{51}$

If standing is about parties, ripeness and mootness are about timing. Ripeness asks if a dispute is sufficiently developed to invoke the power of the federal courts. ${ }^{52}$ Though many well known ripeness cases involve suits to stop the enforcement of statutes or regulations, ${ }^{53}$ ripeness principles apply in private civil litigation as well. ${ }^{54}$ The doctrine of mootness,

whether or not exceeding that sphere will harm one of the other two branches. This case calls for nothing more than a straightforward application of our standing jurisprudence, which, though it may sometimes have an impact on Presidential powers, derives from Article III and not Article II.") (internal citations and quotation marks omitted); see also Clapper v. Amnesty Int'l USA, 133 S. Ct. 1138, 1146 (2013) ("The law of Article III standing, which is built on separation-ofpowers principles, serves to prevent the judicial process from being used to usurp the powers of the political branches.").

49 For sources describing the development and scope of private enforcement in American law, see generally STEPHEN B. BuRBANK \& SEAN FARHANG, RightS AND RETRENCHMENT: THE COUNTERREVOLUTION AGAINST FEDERAL LiTigATION (2017) (analyzing the counterrevolution against private enforcement of rights); SEAN FARHANG, THE Litigation State: PUblic Regulation and PRIVATE LaWsuits IN THE U.S. (2010); Stephen B. Burbank \& Sean Farhang, Litigation Reform: An Institutional Approach, 162 U. PA. L. REV. 1543 (2014); Pamela H. Bucy, Private Justice, 76 S. CAL. L. REV. 1 (2002); Zachary D. Clopton, Redundant Public-Private Enforcement, 69 VAND. L. REV. 285 (2016) [hereinafter Redundant Enforcement]; William B. Rubenstein, On What a "Private Attorney General" Is-And Why it Matters, 57 VAND. L. REV. 2129 (2004); Matthew C. Stephenson, Public Regulation of Private Enforcement: The Case for Expanding the Role of Administrative Agencies, 91 VA. L. REV. 93 (2005).

50 See, e.g., BURBANK \& FARHANG, supra note 49.

51 For a discussion of consumer law, see infra subpart III.A. For the environment, see, for example, Robert V. Percival, Massachusetts v. EPA: Escaping the Common Law's Growing Shadow, 2007 SuP. CT. REV. 111 (2007).

52 See generally RICHARD H. FALLON, JR., ET AL., HART \& WECHSLER'S THE FEDERAL COURTS AND THE FEDERAL SYSTEM 212-37 (7th ed. 2015) [hereinafter HART \& WECHSLER] (explaining the ripeness doctrine); Henry P. Monaghan, Constitutional Adjudication: The Who and When, 82 YALE L.J. 1363, 1365 (1973) (discussing ripeness and related doctrines); Gene R. Nichol, Jr., Ripeness and the Constitution, 54 U. CHI. L. REv. 153, 161-64 (1987) (reviewing the ripeness doctrine).

53 See, e.g., Abbott Labs. v. Gardner, 387 U.S. 136, 137 (1967) (addressing regulations under the Federal Food, Drug, and Cosmetic Act).

54 See, e.g., MedImmune, Inc. v. Genentech, Inc., 549 U.S. 118, 121 (2007) (appealing dismissal of declaratory judgment claims between patent licensee and licensor). 
meanwhile, asks whether a case is "too late" for judicial determination. ${ }^{55}$ Though subject to exceptions, a case "becomes moot only when it is impossible for a court to grant any effectual relief whatever to the prevailing party." 56 So, for example, a plaintiff's acceptance of an offer of judgment moots a dispute because there is no live controversy remaining. 57

Much like standing, Article III ripeness and mootness have their roots in the courts' role in the federal separation of powers. ${ }^{58}$ When courts take cases too soon or too late, they risk "intrud[ing] upon powers vested in the legislative or executive branches. Judicial adherence to the doctrine of the separation of powers preserves the courts for the decision of issues, between litigants, capable of effective determination."59

Federal courts also have held that certain cases are nonjusticiable because they present political questions. ${ }^{60}$ Political

55 See generally HART \& WECHSLER, supra note 52, at 195-212 (reviewing the mootness doctrine); Don B. Kates Jr. \& William T. Barker, Mootness in Judicial Proceedings: Toward a Coherent Theory, 62 CAL. L. REV. 1385, 1401-12 (1974) (providing an overview of the mootness doctrine); Monaghan, supra note 52, at 1383-86 (explaining the development of the mootness doctrine).

56 Chafin v. Chafin, 133 S. Ct. 1017, 1019 (2013) (quoting Knox v. Serv. Emps. Int'l Union, 132 S. Ct. 2277, 2287 (2012)).

57 See, e.g., Genesis Healthcare Corp. v. Symczyk, 133 S. Ct. 1523, 1532 (2013).

58 See, e.g., Zivotofsky ex rel. Zivotofsky v. Clinton, 566 U.S. 189, 206-07 (2012) (discussing when separation-of-powers considerations make abstention appropriate); DaimlerChrysler Corp. v. Cuno, 547 U.S. 332, 352 (2006) (noting that the separation-of-powers limit courts to hearing only cases and controversies); Allen v. Wright, 468 U.S. 737, 750-52, 759-60 (1984) (explaining separation-of-powers concerns prevented a finding of standing).

59 United Pub. Workers v. Mitchell, 330 U.S. 75, 90-91 (1947).

60 See generally HART \& WECHSLER, supra note 52, at 237-66 (reviewing the political question doctrine); Rachel E. Barkow, More Supreme than Court? The Fall of the Political Question Doctrine and the Rise of Judicial Supremacy, 102 CoLUM. L. REV. 237, 244 (2002) (analyzing the Supreme Court's application of the political question doctrine over time); Tara Leigh Grove, The Lost History of the Political Question Doctrine, 90 N.Y.U. L. REv. 1908, 1915 (2015) (explaining the development of the political question doctrine); Martin H. Redish, Judicial Review and the "Political Question," 79 Nw. U. L. REV. 1031, 1033 (1985) (arguing that the political question doctrine should not play a role in judicial review).

In Baker v. Carr, the Supreme Court identified six factors that characterize political questions:

a textually demonstrable constitutional commitment of the issue to a coordinate political department; or a lack of judicially discoverable and manageable standards for resolving it; or the impossibility of deciding without an initial policy determination of a kind clearly for nonjudicial discretion; or the impossibility of a court's undertaking independent resolution without expressing lack of the respect due coordinate branches of government; or an unusual need for unquestioning adherence to a political decision already made; or the potentiality of embarrassment from multifarious pronouncements by various departments on one question. 
questions include the methods of amending the Constitution, ${ }^{61}$ presidential authority to terminate treaties, 62 the republican form of government guarantee, ${ }^{63}$ and Senate authority with respect to impeachment. ${ }^{64}$ And again, the political-question doctrine is about respect for the coordinate branches-it is "essentially a function of the separation of powers."65

Finally, Article III is variously understood to require finality and adversariness. ${ }^{66}$ For example, federal courts refuse to hear cases subject to political-branch revision, ${ }^{67}$ and Chief Justice John Jay famously wrote to President George Washington to decline his invitation to give an advisory opinion. ${ }^{68}$ These limits, too, are linked to the courts' position in the federal separation of powers. ${ }^{69}$

\section{B. Case-or-Controversy Dismissals}

A finding of non-justiciability means that the federal-court suit should end (soon). ${ }^{70}$ But that finding does not necessarily mean the end of the dispute, and it should not mean the end of the enforcement regime. My repeated references to the separation-of-powers origins of the case-or-controversy requirement

369 U.S. 186, 217 (1962).

61 See Coleman v. Miller, 307 U.S. 433 (1939).

62 See Goldwater v. Carter, 444 U.S. 996 (1979).

63 See Luther v. Borden, 48 U.S. 1 (1849).

64 See Nixon v. United States, 506 U.S. 224 (1993).

65 Baker, 369 U.S. at 217. There is some debate about whether the federal political question doctrine necessarily applies in state courts. See, e.g., Backman v. Sec'y of Commonwealth, 441 N.E.2d 523, 526-28 (Mass. 1982) (explaining the role of political question doctrine in Massachusetts); Lawrence Gene Sager, Insular Majorities Unabated: Warth v. Seldin and City of Eastlake v. Forest City Enterprises, Inc., 91 HARV. L. REV. 1373, 1400-01 (1978) (discussing justiciability doctrines in state courts). The arguments against this application are strong, and they are strongest in the non-federal defendant cases that comprise the focus of this article. But this is a separate issue from whether state courts may voluntarily incorporate federal political-question principles.

66 See, e.g., HART \& WECHSLER, supra note 52, at 81-95 (providing an overview of finality and adversariness requirements). But see United States v. Windsor, 570 U.S. 744, 754-63 (2013) (characterizing adversariness as a prudential, not constitutional, requirement).

67 See, e.g., Hayburn's Case, 2 U.S. 408 (1792).

68 See Letter from John Jay to George Washington (Aug. 8, 1793), available at http://press-pubs.uchicago.edu/founders/documents/a3_2_1s34.html [https:/ /perma.cc/U92L-U38R].

69 See, e.g., Hayburn's Case, 2 U.S. 408; HART \& WECHSLER, supra note 52, at 81-95; Letter from John Jay, supra note 68.

70 See, e.g., HART \& WECHSLER, supra note 52, at 204-06 (discussing vacatur after mootness). 
is not just a mantra-it also highlights a set of responses to case-or-controversy dismissals from outside of Article III. ${ }^{71}$

Take standing. When a federal court concludes that a particular plaintiff has not suffered an "injury in fact" such that she may sue to enforce a federal statute, the court says nothing about whether such a suit would be viable in a state court, administrative agency, or legislative tribunal. ${ }^{72}$ More generally, when a federal court interprets Article III to imply any plaintiff bringing a certain type of claim would lack standing, the court says nothing about whether such suits would be viable in state courts, administrative agencies, or legislative tribunals. ${ }^{73}$

First, federal statutes are regularly enforced in state courts. Prior to Reconstruction, there was no grant of general federal-question jurisdiction, ${ }^{74}$ so many federal-law claims were adjudicated in state courts. ${ }^{75}$ Today, many statutes expressly provide for concurrent jurisdiction, ${ }^{76}$ and the Supreme Court has held that state courts must enforce federal law on the same level as analogous state law. ${ }^{77}$ Moreover, state courts are not obligated to follow federal standing rules. ${ }^{78}$ In ASARCO $v$. Kadish, the Supreme Court made clear that state courts may

71 See supra note 3 (discussing “dismissals").

72 See generally Paul M. Bator, The Constitution as Architecture: Legislative and Administrative Courts Under Article III, 65 IND. L.J. 233, 234 (1990) (explaining various approaches to justify non-Article III tribunals); Richard H. Fallon, Jr., Of Legislative Courts, Administrative Agencies, and Article III, 101 HARV. L. REV. 915, 933-49 (1988) (applying the "appellate review" theory to justify non-article III tribunals); James E. Pfander, Article I Tribunals, Article III Courts, and the Judicial Power of the United States, 118 HARV. L. REV. 643, 671-97 (2004) (discussing the history of and justification for Article I tribunals).

73 See Fallon, supra note 72 , at 933-49.

74 "An Act to determine the jurisdiction of circuit courts of the United States, and to regulate the removal of causes from State courts, and for other purposes." 18 Stat. 470, ch. 137 (Mar. 3, 1875). There is a slight exception under the brief reign of the Judiciary Act of 1801. See, e.g., Alison L. LaCroix, Federalists, Federalism, and Federal Jurisdiction, 30 LAW \& HIST. REV. 205, 207 (2012).

75 See, e.g., Richard H. Fallon, Jr., The Ideologies of Federal Courts Law, 74 VA. L. REV. 1141, 1154 (1988); Felix Frankfurter, Distribution of Judicial Power Between United States and State Courts, 13 CoRNELl L.Q. 499, 506 (1928). This long history also implies that there should be no Article I problem stemming merely from the fact that Congress adopted a federal statute enforced only in state court.

76 See, e.g., infra subpart III.A (discussing the FCRA and presumption of concurrency).

77 Testa v. Katt, 330 U.S. 386, 394 (1947).

78 Then-Professor William A. Fletcher argued that "[s]tate courts should be required to adhere to article III 'case or controversy' requirements whenever they adjudicate questions of federal law." The "Case or Controversy" Requirement in State Court Adjudication of Federal Questions, 78 CAL. L. REV. 263, 265 (1990). But as explained shortly, that is not the law. 
adjudicate federal claims that would not satisfy the case-orcontroversy requirement if brought in federal court. ${ }^{79}$ Many states in fact have standing rules looser than Article III. ${ }^{80}$ Therefore, when Article III standing is not available and a state has more liberal standing rules, plaintiffs who file federal claims in state courts may proceed without fear of an Article III dismissal (or a successful removal to federal court). ${ }^{81}$

For example, claims for civil rights violations under the highly important (and often contentious) Section 1983 may be brought in federal or state courts. ${ }^{82}$ Of course, Section 1983 suits in federal court are subject to Article III standing, but what if such suits are brought in state court? In Keyhea $v$. Rushen, for example, California taxpayers sued under Section 1983 alleging third-party harms to prisoners from the use of psychotropic drugs against their will. ${ }^{83}$ Taxpayer standing for 1983 claims is unavailable in federal court, but permissible in California state court. ${ }^{84}$ As a result, plaintiffs were able to press their federal claim in state court despite lacking a federally justiciable case or controversy. ${ }^{85}$ Of course, this assumes a federal statute with concurrent jurisdiction and a state with

79 ASARCO Inc. v. Kadish, 490 U.S. 605, 617 (1989) ("We have recognized often that the constraints of Article III do not apply to state courts, and accordingly the state courts are not bound by the limitations of a case or controversy or other federal rules of justiciability even when they address issues of federal law, as when they are called upon to interpret the Constitution or, in this case, a federal statute.").

80 See, e.g., Helen Hershkoff, State Courts and the "Passive Virtues": Rethinking the Judicial Function, 114 HARV. L. REV. 1833, 1852-59 (2001) (comparing federal standing rules with standing rules in state courts); F. Andrew Hessick, Cases, Controversies, and Diversity, 109 Nw. U. L. REv. 57, 65-68 (2015) (explaining the variance between state and federal standing doctrine). For an example that got the attention of the Supreme Court, see Nike, Inc. v. Kasky, 539 U.S. 654, 667-70 (2003) (per curiam) (Stevens, J., concurring) (noting that California's unfair-competition law allowed a private attorney general to sue Nike for misrepresentations regarding foreign working conditions in state court even though plaintiff would not have been able to establish Article III standing).

81 See 28 U.S.C. $\$ 1441$ (2018). I situate these responses within a broader framework in Zachary D. Clopton, Procedural Retrenchment and the States, 106 CAL. L. REV. 411 (2018).

82 See Haywood v. Drown, 556 U.S. 729, 731 (2009); Patsy v. Bd. of Regents of Fla., 457 U.S. 496, 506-07 (1982); Maine v. Thiboutot, 448 U.S. 1, 3 n.1 (1980).

835 Cal. Rptr. 2d 762 (1992).

84 See Cal. Civ. Proc. Code § 526a (Deering 2017).

85 Ultimately, the plaintiffs did not prevail on their Section 1983 claim, but they were able to obtain attorney fees under Section 1988 because their successful state-law claim was factually related to the federal claim. See Keyhea, 5 Cal. Rptr. 2d at 762. 
broad standing law. ${ }^{86}$ Why Congress and a state might operate in this way is taken up below. 87

In addition to state-court resolution, when a federal court dismisses a suit for lack of standing, Congress could understand this dismissal as an invitation to create a non-Article III federal process. Most prominently, agency adjudication is not subject to the strictures of Article III standing. In the words of the D.C. Circuit, "[w]ithin their legislative mandates, agencies are free to hear actions brought by parties who might be without party standing if the same issues happened to be before a federal court." 88 In Ritchie $v$. Simpson, for example, William Richie was able to challenge O.J. Simpson's applications to register the trademarks O.J. SIMPSON, O.J., and THE JUICE as immoral and scandalous in the Trademark Trial and Appeal Board (TTAB) merely on the basis of Ritchie's claim to be a "family man" who believed that the "sanctity of marriage requires a husband and wife who love and nurture one an-

86 Indeed, some state courts have applied federal standing principles in state Section 1983 cases on the theory that federal standing doctrine inhered to the federal statute. See, e.g., Steven H. Steinglass, Section 1983 Litigation in State COURTS § 6.4 (2016) (collecting examples of states mirroring and not mirroring federal pleading standards for Section 1983 claims in state courts).

87 See infra Part III. Though not adjudicating a federal statutory cause of action, another useful illustration of the state-court option arose in Envtl. World Watch, Inc. v. Am. Airlines, Inc., No. C05-1799 TEH, 2005 WL 1867728 (N.D. Cal. Aug. 3, 2005). California's Proposition 65 required businesses that operate or sell products in California to warn their employees if they were exposed to certain chemicals, and it broadened state standing doctrine to permit suits by private parties "in the public interest." Id. at *3. Taking advantage of Prop 65, Environment World Watch (EWW) filed suit in state court against various airlines operating in California, even though EWW had not suffered any injury in fact. The airline defendants removed the case to federal court, but because EWW lacked Article III standing, the case was remanded to state court. Id. What makes this case noteworthy is that one of those airline defendants was the state-owned airline of New Zealand. The Foreign Sovereign Immunities Act purportedly provides federal-court jurisdiction for suits against foreign sovereigns, see 28 U.S.C. $\S 1330$ (2018), but because of the Article III problem, the New Zealand airline was forced to defend that case in state court.

88 Gardner v. FCC, 530 F.2d 1086, 1090 (1976). See also Pittsburgh \& W. Va. R.R. Co. v. United States, 281 U.S. 479, 486 (1930) ("The mere fact that appellant was permitted to intervene before the [administrative agency] does not entitle it to institute an independent suit [in federal court] to set aside the [agency's] order in the absence of resulting actual or threatened legal injury to it."); HENRY J. FRIENDLY, FEDERAL JURISDICTION: A GENERAL VIEW 118 (1973) (noting the various factors that "negate any general rule linking a person's standing to seek judicial review to the fact that he has been allowed to intervene before the agency"); 13A Charles A. Wright, Arthur R. Miller, and Edward H. Cooper, Federal Practice and Procedure, § 3531.13, at 80 (1984 \& Supp. 1997) ("Administrative agencies are not established under Article III and should not be bound by judicial rules of standing in determining what parties to admit to adjudicatory or rulemaking proceedings, any more than they are bound by other judicial rules of procedure."). 
other."89 It is hard to imagine Ritchie convincing a federal court that he should have Article III standing to challenge the applications, but the Federal Circuit concluded that this was sufficient to proceed in the TTAB. ${ }^{90}$ Similarly, in proceedings from the Federal Energy Regulatory Commission ${ }^{91}$ to the Federal Communications Commission ${ }^{92}$ to the Department of the Interior, ${ }^{93}$ plaintiffs have gained access to administrative adjudication without complying with Article III. Legislative courts also could be made available, insulated from Article III standing, should Congress so choose. ${ }^{94}$

These non-Article III options have particular salience in light of recent decisions on private enforcement. During the second half of the 20th century, Congress has relied heavily on private parties to enforce various federal statutes. Professors Burbank and Farhang (and others) have documented the trend-and associated backlash. ${ }^{95}$ The thrust of their argument is that the Supreme Court has been more effective than Congress in rolling back the private-enforcement revolution.96 However, had previous congresses created non-Article III mechanisms to go along with private-enforcement rights, attempts to limit enforcement through justiciability doctrine would have fallen short. ${ }^{97}$

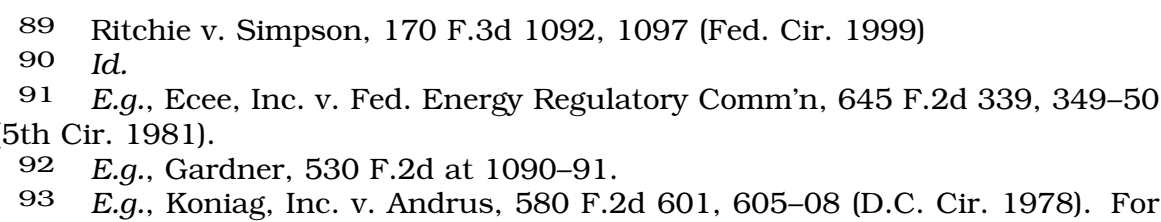
another interesting example, note that any person-not only one alleging an injury in fact-can file a complaint of judicial misconduct with the Judicial Council of the circuit courts. E.g., In re Complaints of Judicial Misconduct, 9 F.3d 1562 (U.S. Jud. Conf. 1993).

94 See supra note 72.

95 See supra note 49 (collecting work of Burbank, Farhang, and others). See also, e.g., J. Maria Glover, The Structural Role of Private Enforcement Mechanisms in Public Law, 53 WM. \& MARY L. REV. 1137 (2012).

96 BURBANK \& FARHANG, supra note 49. In other words, previous congresses' efforts to entrench their substantive preferences through private enforcement were thwarted by the courts' ability to close their doors. For more on intertemporal preferences, see infra note 238 and accompanying text.

97 In the wake of various standing decisions that seemed to hamper the private enforcement of environmental statutes, an occasional commentator would call for the creation of non-Article III tribunals to handle environmental claims. See, e.g., Preston Carter, Note, "If an (Endangered) Tree Falls in the Forest, and No One Is Around . . . .": Resolving the Divergence Between Standing Requirements \& Congressional Intent in Environmental Legislation, 84 NOTRE DAME L. REV. 2191, 2212-22 (2009); James Dumont, Beyond Standing: Proposals for Congressional Response to Supreme Court "Standing" Decisions, 13 VT. L. REV. 675, 684-89 (1989); Timothy C. Hodits, Note, The Fatal Flaw of Standing: A Proposal for an Article I Tribunal for Environmental Claims, 84 WASH. U. L. REV. 1907, 1907 (2006); 
Case-or-controversy dismissals for reasons other than standing also might be understood as calls for Congress to act. Sometimes Congress may create statutory schemes that require judgments that appear advisory or non-final. ${ }^{98}$ If a federal court were to reject such an approach on Article III grounds, Congress could create an administrative or legislative tribunal to do the work. For example, for most of its history, Court of Claims judges handled both independent suits against the government and so-called congressional-references cases, in which they issued advisory opinions over which Congress had final say. ${ }^{99}$ In Glidden Co. v. Zdanok, the Supreme Court confirmed that the Court of Claims was an Article III tribunal. ${ }^{100}$ Following Glidden, the Article III judges of the Claims Court refused to issue advisory opinions in congressional-reference cases. Rather than despair the loss of those determinations, Congress simply assigned the work to Article I commissioners instead. ${ }^{101}$ Similarly, the Administrative Procedure Act authorizes agencies to issue "declaratory judgments," 102 and Article III does not seem to require those proceedings to involve justiciable cases or controversies. ${ }^{103}$ State courts, too, could hear "advisory opinion" cases under federal law if consistent with state justiciability principles. ${ }^{104}$

Finally, one could imagine similar patterns for mootness and ripeness, though as discussed below, ripeness may pre-

David Krinsky, How to Sue Without Standing: The Constitutionality of Citizen Suits in Non-Article III Tribunals, 57 CASE W. RES. L. REV. 301, 308 (2007). See also Elliott, supra note 26, at 206 (arguing against such proposals).

98 See supra notes 66-69 and accompanying text.

99 See, e.g., Pfander, supra note 72, at 657, 704-05.

100370 U.S. 530 (1962).

101 See Federal Courts Improvement Act of 1982, Pub. L. No. 97-164, sec. 105, $\S 171$ (b) (codified as amended at 28 U.S.C. \$\$ 171-77 (2000)).

102 See 5 U.S.C. § 554(e) (2018) ("The agency, with like effect as in the case of other orders, and in its sound discretion, may issue a declaratory order to terminate a controversy or remove uncertainty.").

103 See, e.g., Cent. Freight Lines v. I.C.C., 899 F.2d 413, 417 (5th Cir. 1990) (explaining that it is "well established that the case or controversy requirement of Article III does not restrict an agency's authority to issue declaratory rulings under 5 U.S.C. § 554(e)”) (internal quotation marks omitted); see also Emily S. Bremer, The Agency Declaratory Judgment, 78 OHIO ST. L.J. 1169 (2017). Indeed, it would be odd to suggest that Article III applied to agency declaratory proceedings but not to other agency adjudications.

104 See ASARCO, Inc. v. Kadish, 490 U.S. 605, 620 (1989) (noting “established traditions and ... prior decisions recognizing that the state courts are not bound by Article III and yet have it within both their power and their proper role to render binding judgments on issues of federal law, subject only to review by this Court"); id. at 636 (Rehnquist, C.J., concurring in part and dissenting in part) (noting the "unremarkable proposition . . . [that] state courts render advisory decisions on federal law of no binding force even within the State"). 
sent a special concern not present for other justiciability doctrines. 105

\section{The Judicial Power of the United States}

Stated simply, the previous subpart suggests that a caseor-controversy dismissal could be understood as an opportunity for non-Article III resolution. But observers of federal courts might have a sneaking suspicion that this claim is too bold. For various textual, historical, and functional reasons, the Supreme Court has placed limits on the types of disputes that Congress may assign to non-Article III tribunals, and these limits have generated significant judicial and scholarly attention. One might think, therefore, that these limits also should cut back on my dismissal-as-invitation thesis. To better understand this issue, this subpart surveys the jurisprudential landscape with respect to the judicial power, ${ }^{106}$ and then explains why (for the most part) it should not affect the disputes described in this Article.

In addition to the case-or-controversy requirement (and other provisions not relevant here ${ }^{107}$ ), Article III establishes an important limit on federal dispute resolution when it provides that "[t]he judicial Power of the United States, shall be vested in one supreme Court, and in such inferior Courts as the Congress may from time to time ordain and establish." 108 Understood as an important bulwark of the separation of powers, ${ }^{109}$ the vesting clause seems to imply a mandatory rule-by using "shall," the Constitution declares that the judicial power may be exercised only by the federal judicial branch. ${ }^{110}$ Although a few recent scholars have aspired to Article III literalism, ${ }^{111}$ history seems to cut the other way. Military, territorial, and public-rights disputes have been adjudicated outside of Article III

\footnotetext{
105 See infra notes 141-44 and accompanying text.

106 For a curious reader, then-Judge Gorsuch surveyed much of the history in In re Renewable Energy Dev. Corp., 792 F.3d 1274 (10th Cir. 2015).

107 Article III, Section 2 also addresses original jurisdiction and criminal cases; Article III, Section 3 addresses treason. U.S. ConST. art. III, §§ 2-3.

108 U.S. CONST. art. III, § 1.

109 See infra notes 112-20 and accompanying text.

110 Shall is typically understood as mandatory. See, for example, Nat'l Ass'n of Home Builders v. Defs. of Wildlife, 551 U.S. 644, 661-62 (2007); Lopez v. Davis, 531 U.S. 230, 241 (2001); Lexecon Inc. v. Milberg Weiss Bershad Hynes \& Lerach, 523 U.S. 26, 35 (1998), though not always, for example, Town of Castle Rock v. Gonzales, 545 U.S. 748, 761 (2005). See also A. SCALIA \& B. GARNER, READING LAW: THE INTERPRETATION OF LEGAL TEXTS 114 (2012) (“[W]hen the word shall can reasonably read as mandatory, it ought to be so read.").

111 See Pfander, supra note 72, at n.8 (collecting sources).
} 
for centuries, though Murray's Lessee teaches the default rule that Congress may not "withdraw from judicial cognizance any matter which, from its nature, is the subject of a suit at the common law, or in equity, or admiralty . . . ."112

More recent decisions have explored the line between those cases or controversies that can and cannot be adjudicated outside of Article III. In Northern Pipeline, the Supreme Court adopted a so-called categorical approach based on the history of non-Article III tribunals, ${ }^{113}$ though the Court quickly abandoned this method in favor of a balancing approach presaged in Justice White's Northern Pipeline dissent.114 In Schor, the Court explained that federal courts must balance the goals of Congress with the need for an independent judiciary to "determin[e] the extent to which a given congressional decision to authorize the adjudication of Article III business in a nonArticle III tribunal impermissibly threatens the institutional integrity of the Judicial Branch."115 In Granfinanciera, Justice Brennan suggested a correspondence between Article III and the Seventh Amendment, which preserved the jury right for suits at common law. ${ }^{116}$

The Roberts Court addressed the federal judicial power in a pair of cases arising out of bankruptcy proceedings. First, in Stern, the Supreme Court again reiterated the existence of some "public rights" disputes that could find a non-Article III home, but also concluded that mere characterization of a case as related to a public right was not enough: "[Congress] may no more lawfully chip away at the authority of the Judicial Branch than it may eliminate it entirely." 117 Finally, in 2015, the Supreme Court in Wellness International recalled Schor's concern with "institutional integrity of the Judicial Branch."118 The majority in Wellness International concluded that Congress had not attempted to "aggrandize itself or humble the Judiciary" by providing for non-Article III adjudication of cases or controversies. ${ }^{119}$ Again relying on Schor, the Court commented that the law was far from the extreme scenario presented by

112 Murray's Lessee v. Hoboken Land \& Improvement Co., 59 U.S. 272, 284 (1855).

113 N. Pipeline Constr. Co. v. Marathon Pipe Line Co., 458 U.S. 50, 63-70 (1982).

114 Id. at 113-16.

115 Commodity Futures Trading Comm'n v. Schor, 478 U.S. 833, 851 (1986).

116 Granfinanciera, S.A. v. Nordberg, 492 U.S. 33, 64 (1989).

117 Stern v. Marshall, 564 U.S. 462, 502-03 (2011).

118 Wellness Int'l Network, Ltd. v. Sharif, 135 S. Ct. 1932, 1944 (2015).

119 Id. at 1945. 
detractors: it was not as if "Congress created a phalanx of nonArticle III tribunals equipped to handle the entire business of the Article III courts without any Article III supervision or control and without evidence of valid and specific legislative necessities." 120

Upon first glance, the proposal to treat case-or-controversy dismissals as invitations for non-Article III adjudication seems to fit within this long-running debate, so readers might expect here an explanation why adjudicating these cases outside of the federal courts would fit in some historical category or would satisfy the Court's balancing test. But, the judicial power limit does not affect the jurisdiction of state courts, and even for non-Article III federal tribunals, my thesis avoids this debate altogether. ${ }^{121}$ The issues described in the preceding paragraphs address when Congress can assign Article III-type disputes to non-Article III tribunals. By very definition, a suit dismissed on the basis of the case-or-controversy requirement is not an Article III dispute at all. ${ }^{122}$ Consider the underlying disputes in the recent cases addressing the vesting clause:

- In Northern Pipeline, the plaintiff "sought damages for alleged breaches of contract and warranty, as well as for alleged misrepresentation, coercion, and duress"; 123

- In Schor, the relevant dispute was a claim under state law to recover a debit balance; ${ }^{124}$

- In Granfinanciera, the Court discussed claims for fraudulent transfers traditionally brought at law; ${ }^{125}$

- In Stern, the Court addressed tortious interference; 126 and

- In Wellness International, the Court addressed itself to an alter-ego claim under state law. ${ }^{127}$

In each of these cases, an Article III case or controversy could have been articulated. Not so when a court finds a lack of standing, mootness, or an advisory opinion. ${ }^{128}$

120 Id. at 1947.

121 As discussed below, the situation may be slightly more complicated for some unripe claims. See infra notes 141-44 and accompanying text.

122 See supra subpart I.A.

123 N. Pipeline Constr. Co. v. Marathon Pipe Line Co., 458 U.S. 50,56 (1982). In Thomas, a related case not described above the line, the dispute was a statelaw contract claim. See Thomas v. Union Carbide Agric. Prods. Co., 473 U.S. 568 (1985).

124 Commodity Futures Trading Comm'n v. Schor, 478 U.S. 833 (1986).

125 Granfinanciera, S.A. v. Nordberg, 492 U.S. 33 (1989).

126 Stern v. Marshall, 564 U.S. 462 (2011).

127 Wellness Int'l Network, Ltd. v. Sharif, 135 S. Ct. 1932 (2015).

128 See supra subpart I.A. 
One could reach the same conclusion based on any of the major approaches to the judicial-power limit. ${ }^{129}$ Balancers worry about threats to the integrity of the courts or attempts to humble the judiciary, ${ }^{130}$ but how could the disposition of a dispute that the federal courts cannot constitutionally resolve threaten or humble the judicial branch? Categorical formalists draw exceptions within Article III for certain types of disputes, ${ }^{131}$ but the claims addressed here are not within Article III at all. When Justice Brennan connected Article III to the Seventh Amendment, ${ }^{132}$ he implicitly recognized that the scope of Article III is tied to those suits at common law for which the Seventh Amendment preserves the right to a jury, but there would be no jury right to preserve if there was no case or controversy to begin with. ${ }^{133}$ And even for the few-and-farbetween literalists, ${ }^{134}$ a mandatory judicial-power should still permit non-Article III courts to resolve non-Article III disputes. So, while a case-or-controversy dismissal takes away federalcourt dispute resolution with one hand, it invites legislative creativity by removing the judicial-power limit with the other.

In addition to uniting these various factions, the dismissalas-invitation thesis also avoids two other debates that divide judges and scholars. First, depending on one's reading of the Constitution, Article III supervision of non-Article III courts may be required. ${ }^{135}$ But this debate is simply orthogonal to the claim here-my suggested alternatives work whether or not Article III supervision is required, and indeed the Supreme Court has countenanced review of some state court decisions for which Article III standing would not be available. ${ }^{136}$

129 I would also note that both sections of Article III discuss the "judicial power," suggesting (though not requiring) symmetry between the two. See U.S. Const. art. III, § 1 ("The judicial Power of the United States, shall be vested . . ."); § 2 ("The judicial Power shall extend . . ."); see also Akhil Reed Amar, Intratextualism, 112 HARV. L. REV. 747, 791 (1999) (describing a methodology of constitutional interpretation that uses the Constitution as a "dictionary" to define its own terms). But see Adrian Vermeule \& Ernest A. Young, Commentary, Hercules, Herbert, and Amar: The Trouble with Intratextualism, 113 HARV. L. REV. 730 (2000) (critiquing Amar's Intertextualism). However, nothing here turns on this (intra)textual analysis.

130 See supra notes 114-15 and accompanying text.

131 See supra notes 113 and accompanying text.

132 Granfinanciera, S.A. v. Nordberg, 492 U.S. 33 (1989).

133 Note also that the Seventh Amendment does not apply to state courts. See infra note 146 and accompanying text.

134 See supra note 113 and accompanying text.

135 See Pfander, supra note 72, at 721-31 (discussing this requirement).

136 ASARCO, Inc. v. Kadish, 490 U.S. 605 (1989). With respect to Article I or Article II solutions, if supervision were required (or desired), the non-Article III resolution itself might create a case or controversy even if the original dispute did 
Whatever one's view of this supervisory question, it can be imported into my scheme. ${ }^{137}$ Second, some of the recent Article III decisions have turned on the role of party consent. ${ }^{138}$ But consent is irrelevant to the jurisdictional question whether a party articulates a case-or-controversy. ${ }^{139}$ In addition, when legislators consider an invitation to authorize non-Article III resolution, they seemingly would be permitted to make their own choice about the importance of party consent. ${ }^{140}$

The conclusory language of this Part with respect to Article III's inapplicability to non-Article III claims may require more thought when applied to the doctrine of ripeness. ${ }^{141}$ Specifically, ripeness may pose special challenges for those justices that treat the judicial-power limit as protecting the integrity of the judicial branch. ${ }^{142}$ Non-Article III adjudication of claims for which there is no standing or which are moot should not humble the judicial branch. Ripeness is potentially different, in that it might humble the judicial branch to take away a set of cases that in time may ripen into Article III disputes. ${ }^{143}$ Indeed, a decision on ripeness might expressly identify the circumstances under which a premature claim might ripen into a case or controversy. The consequence, therefore, is that the constitutional analysis of this Part is less straightforwardly ap-

not do so. See Pfander, supra note 72, at 724-31 (noting some historical tools such as officer suits and common-law writs).

137 The possibility for federal appellate review might ameliorate concerns that state courts or administrative agencies could not (formally) or should not (functionally) have the last word on federal claims.

138 See, e.g., Wellness Int'l Network, Ltd. v. Sharif, 135 S. Ct. 1932, 1942-49

(2015) ("Article III is not violated when the parties knowingly and voluntarily consent to adjudication by a bankruptcy judge."); see also F. Andrew Hessick, Consenting to Adjudication Outside the Article III Courts, 71 VAND. L. REV. 715, 718 (2018) (criticizing the consent exception to Article III).

139 Sosna v. Iowa, 419 U.S. 393, 398 (1975) ("While the parties may be permitted to waive nonjurisdictional defects, they may not by stipulation invoke the judicial power of the United States in litigation which does not present an actual "case or controversy.").

140 Subject to due process and other constraints described infra Part II, of course.

141 See supra notes 52-54 and accompanying text.

142 See, e.g., Wellness Int'l Network, Ltd. v. Sharif, 135 S. Ct. 1932, 1942-47

(2015) (finding that Article III allows bankruptcy judges to decide cases for final adjudication with the parties' knowing and voluntary consent); Stern v. Marshall, 564 U.S. 462, 482-87 (2011) (holding that the bankruptcy court lacked authority under Article III to enter a final judgment on a counterclaim); Commodity Futures Trading Comm'n v. Schor, 478 U.S. 833, 851-57 (1986) (concluding that agency jurisdiction over state law claims incident to adjudication of federal claims does not violate Article III).

143 See, e.g., Wellness, 135 S. Ct. at 1944-46 (explaining that Congress did not attempt to humble the Judiciary when Congress gave jurisdiction over the claims at issue to the bankruptcy courts). 
plicable to unripe claims in non-Article III federal tribunals. At a minimum, though, ripe non-justiciable claims should be possible candidates for non-Article III resolution. ${ }^{144}$

\section{II}

\section{NON-ARTICLE III LIMITS}

The previous Part centered on a straightforward idea: if it is not an Article III dispute, then Article III does not place limits on its resolution. This Part briefly turns to an alternative view: if it is not an Article III dispute, what non-Article III limits are relevant?

One potential limit comes from the Constitution's guarantee in the Seventh Amendment that "the right of trial by jury shall be preserved." 145 As both a textual and theoretical matter, the jury right is not necessarily limited to suits in federal court, and therefore it could provide a limit with respect to nonArticle III adjudication. Current doctrine, however, seems to suggest that the Seventh Amendment in fact provides no limit in these cases. The Supreme Court has held that the Seventh Amendment is not incorporated against the states. ${ }^{146}$ Further, although the explanation has not been entirely clear, the Court seems to understand the Seventh Amendment to be inapplicable in non-Article III federal adjudication as well. ${ }^{147}$ Even if the Court were to conclude that the Seventh Amendment extends outside of the Article III courts, the cases described here seem like particularly poor candidates for that extension-the Seventh Amendment "preserves" the jury right that existed at common law, and it seems unlikely that the Court would find a preexisting jury right for suits that were not "cases or contro-

144 My own view is that, for ripeness, judicial-power "balancers" might adopt a more fine-grained assessment of the effect of a particular non-Article III federal resolution on the judicial power. Non-balancers would have no obvious reason to treat ripeness differently.

145 U.S. CONST. amend. VII.

146 See Pearson v. Yewdall, 95 U.S. 294, 296 (1877) (“[A]rt. 7 of the amendments to the Constitution of the United States relating to trials by jury applies only to the courts of the United States . . . .").

147 In the words of Professor Sward,

The Court has said that the Article III and Seventh Amendment analyses are the same, so that if the public rights doctrine or the balancing test allows Congress to assign a matter to a non-Article III court, it can do so without providing for a jury. The cases, however, are not entirely consistent with that statement.

Ellen E. Sward, Legislative Courts, Article III, and the Seventh Amendment, 77 N.C. L. REV. 1037, 1098 (1999); see also Martin H. Redish \& Daniel J. La Fave, Seventh Amendment Right to Jury Trial in Non-Article III Proceedings: A Study in Dysfunctional Constitutional Theory, 4 WM. \& MARY BILL RTS. J. 407, 417-29 (1995). 
versies" within the "judicial power." 148 Even if the court were to find such a limit, it still does not require an Article III resolution-Congress could require a jury, and indeed juries in state courts and legislative courts are commonplace. ${ }^{149}$

While the application of the Seventh Amendment is somewhat tenuous, the Due Process Clause clearly places limits on non-Article III adjudication (including in state courts). This is not the place to articulate every detail of the process due, but I would be remiss if I did not mention the seminal decision in Mathews $v$. Eldridge. ${ }^{150}$ Mathews famously adopted a balancing test for due process, which accounts for three classes of considerations: (i) the private interest; (ii) the risk of erroneous deprivation and the value of additional safeguards; and (iii) the government's interest. ${ }^{151}$ Certainly, any congressional or state response to a dismissal-as-invitation would need to satisfy due process, but it seems reasonable to expect that (at least eventually) Congress and the states could authorize a satisfactory process. ${ }^{152}$

Many other constitutional constraints on legislative and executive authority also may be implicated, though those implications are not special to the cases discussed in this Article. Whatever limits are derived from federalism considerations ${ }^{153}$ or Congress's enumerated powers, ${ }^{154}$ those limits apply to these non-Article III adjudications. To the extent that Congress cannot abridge the freedom of speech, ${ }^{155}$ impose excessive

148 More likely candidates, I presume, would be cases that fall within Article III but for balancing reasons are permitted in non-Article III tribunals. See supra notes 114-20 and accompanying text.

149 For example, territorial courts and courts martial may employ juries. Congress also could provide for a jury for policy reasons even if one were not constitutionally required.

150424 U.S. 319 (1976).

151 Id. at 335.

152 Heather Elliott has explored some of the due process issues that may arise for legislative tribunals in Congress's Inability to Solve Standing Problems, 91 B.U. L. REV. 159 (2011). My claim here is not that non-Article III tribunals are per se acceptable under the Due Process Clause. But as long as due process does not require an "Article III judge," a committed legislature should be able to design tribunals that satisfy constitutional requirements. The contrary approach would be deeply formalist - reading the Due Process Clause as satisfied by an Article III judge only and not by any functional equivalent-and yet untethered from Article III's formal requirement of a "case or controversy."

153 E.g., U.S. CONST. amend. X.

154 E.g., U.S. ConsT. art. I, § 8, cl. 3 (Commerce Clause).

155 U.S. CONST. amend. I. 
fines, ${ }^{156}$ or deny equal protection of the laws, ${ }^{157}$ it cannot do so in these cases. ${ }^{158}$

When state courts are involved, state law also may limit the availability of relief in these cases. The Supreme Court has made clear that states may regulate their courts in certain ways that seemingly reduce court access for federal claims. ${ }^{159}$ For example, states may have narrower standing doctrines than Article III, and those may apply to some federal claims brought in state court. ${ }^{160}$ State constitutions, state statutes, and state judicial decisions may create limits both on the availability of state courts and on the acceptable procedures and remedies they may provide. These limits seemingly would apply here too, as long as they do not discriminate against federal actions. ${ }^{161}$

Layered on top of these legal limits are additional normative or policy constraints. ${ }^{162}$ For example, there has been significant criticism of federal law's deference to arbitration agreements because arbitration may undermine some of the important values of public adjudication. ${ }^{163}$ Something is lost, the line goes, when courts are kept out. ${ }^{164}$ Without passing

\section{U.S. CONST. amend. VIII.}

157 U.S. CONST. amend. V.

158 The Court also has taken an expansive view of state sovereign immunity under the Eleventh Amendment, so even though the amendment's text refers to the "judicial power," the Court has refused congressional attempts to abrogate state sovereign immunity in agency adjudication. Fed. Mar. Comm'n v. S.C. State Ports Auth., 535 U.S. 743, 751-54 (2002). These limits apply here as well.

159 See supra notes 77-80.

160 See Vill. of Arlington Heights v. Metro. Hous. Dev. Corp., 429 U.S. 252, 261-63 (1977).

161 See, e.g., Howlett v. Rose, 496 U.S. 356, 361-65, 375-81 (1990) (holding that a state-law defense is unavailable in a $\S 1983$ action brought in state court if that defense would be unavailable in a federal forum); Haywood v. Drown, 556 U.S. 729 (2009) (declaring a state law unconstitutional because it prohibited an inmate from bringing a $\$ 1983$ claim).

162 These constraints, of course, may have more or less constitutional grounding.

163 See, e.g., Einer Elhauge, How Italian Colors Guts Private Antitrust Enforcement by Replacing It with Ineffective Forms of Arbitration, 38 FORDHAM INT'L L.J. 771 (2015) (contending that recent Supreme Court decisions have replaced private antitrust enforcement with ineffective forms of arbitration); Judith Resnik, Diffusing Disputes: The Public in the Private of Arbitration, the Private in Courts, and the Erasure of Rights, 124 YALE L.J. 2804, 2822-25, 2893-900 (2015) (arguing that the Supreme Court's decisions on arbitration have created an unconstitutional system); Judith Resnik, Fairness in Numbers: A Comment on AT\&T v. Concepcion, Wal-Mart v. Dukes, and Turner v. Rogers, 125 HARV. L. REV. 78, 82-87, 154-161 (2011) (explaining that recent Supreme Court decisions on arbitration have created due process concerns). "Public" here has at least two meanings: public as in "open to the public" and public as in governmental.

164 See also Owen M. Fiss, Against Settlement, 93 YALE L.J. 1073, 1075 (1984). 
judgment on these particular claims, I would simply note that the alternative tribunals discussed here could be designed to accommodate these normative concerns. ${ }^{165}$ These too are matters that Congress and the states are invited to consider.

Finally, institutional design considerations may augur in favor of administrative tribunals or state courts. Any number of considerations could be relevant here, but I will restrict myself to three that seem particularly salient. First, one could imagine Congress concluding that certain topics demand national solutions (e.g., foreign affairs) ${ }^{166}$ or subject-matter expertise (e.g., bankruptcy). ${ }^{167}$ To the extent that Congress concludes that state-court judges lack the expertise to handle a certain class of disputes, it might seek to make federal administrative resolution the exclusive forum. Second, whether for legal or historical reasons, both federal and state courts are somewhat limited in the form that their proceedings may take. While many bilateral disputes are well within the scope of these procedural forms, Congress might conclude that certain polycentric, policy-laden disputes are better handled within a more flexible process. ${ }^{168}$ This too could counsel for administrative solutions.

On the other hand, there may be situations in which state options present particular benefits for the regulatory regime. In recent years there has been growing attention on, in the words of a prominent proponent, "federalism as the new nationalism." 169 Scholars of this "new new federalism" have observed the increasingly significant role of states in national policy, and they have offered normative support for this development. ${ }^{170}$ For example, the ability of states to experiment and diversify-and to challenge federal policy preferences-could spur changes in policy at the federal and state levels that redound in favor of deeper enforcement. ${ }^{171}$ These options could

165 Indeed, the political branches could make special provision for non-Article III resolution of claims seemingly relegated to ineffective arbitration. See Clopton, Procedural Retrenchment, supra note 81, at 13.

16628 U.S.C. § 1330 (2018) (actions against foreign states).

16728 U.S.C. § 1334(a) (2018).

168 See, e.g., Lon Fuller, The Forms and Limits of Adjudication, 92 HARV. L. REV. 353, 394-404 (1978) (addressing adjudication in polycentric situations).

169 See Gerken, supra note 28, at 1890; Symposium, Federalism as the New Nationalism, supra note 28.

170 See Gerken, supra note 28; Symposium, Federalism as the New Nationalism, supra note 28 .

171 See Gerken, supra note 28, at 1904; Symposium, Federalism as the New Nationalism, supra note 28; see also New State Ice Co. v. Liebmann, 285 U.S. 262, 311 (1932) (Brandeis, J., dissenting) ("It is one of the happy incidents of the federal system that a single courageous state may, if its citizens choose, serve as a 
become even more important if Congress concludes that the states are better positioned to enforce important federal laws than the current occupants of the federal executive branch. ${ }^{172}$

In sum, when federal courts find that a dispute is not a case or controversy, Congress should understand that conclusion as an invitation to non-Article III resolution. Of course, such resolution must comply with other constitutional requirements, but it need not rely on the federal courts in the first instance. ${ }^{173}$ This conclusion is consistent with the underlying logic of Article III's case-or-controversy requirement and vesting of the judicial power. Both of those provisions rely on a deep-rooted principle of the separation of powers, and so it makes sense that the application of Article III conduces to additional space for those separated powers to act. In this light, the next Part looks more closely at how Congress (and the states) may respond to federal-court invitations that take the form of Article III dismissals.

III

ApPlications, SMALl AND LARGE

\section{A. Writ Small: Spokeo v. Robins}

Spokeo is a "people search engine" that aggregates information about individuals from a range of sources. ${ }^{174}$ Thomas Robins was one such individual. Spokeo.com reported that Robins held a graduate degree and was wealthy. Both of these statements, according to Robins himself, were untrue. ${ }^{175}$ Robins sued under the Fair Credit Reporting Act (FCRA), ${ }^{176}$ which provides for recovery in cases in which a defendant willfully fails to follow "reasonable procedures to assure maximum possible accuracy" of consumer reports. ${ }^{177}$

laboratory; and try novel social and economic experiments without risk to the rest of the country."); Larry Kramer, Understanding Federalism, 47 VAND. L. REV. 1485, 1499 (1994).

$172 C f$. FARHANG, supra note 49 (making this point for private enforcement).

173 I say "in the first instance" to acknowledge potential requirements for Article III supervision. See supra note 135 and accompanying text.

174 See About Us, SPOKEO, http://spokeo.com/about [https://perma.cc/ 6GAR-2Z8Z].

175 Robins v. Spokeo, Inc., 742 F.3d 409, 411 (9th Cir. 2014), vacated by 136

S. Ct. 1540 (2016).

176 See id. at 410; 15 U.S.C. § 1681 (2018).

177 See 15 U.S.C. § $1681 \mathrm{e}(\mathrm{b})$ (2018). 
A federal district court dismissed Robins's complaint for lack of standing because Robins failed to allege any actual or imminent harm resulting from the alleged statutory violations: "Mere violation of the Fair Credit Reporting Act does not confer Article III standing . . . where no injury in fact is properly pled."178 The Ninth Circuit reversed, but the Supreme Court granted cert to decide "[w]hether Congress may confer Article III standing upon a plaintiff who suffers no concrete harm, and who therefore could not otherwise invoke the jurisdiction of a federal court, by authorizing a private right of action based on a bare violation of a federal statute." 179

Following the death of Justice Scalia, the Supreme Court issued an incremental opinion remanding the case for further development about the "concreteness" of Robins's claims. ${ }^{180}$ The decision confirmed that "Congress cannot erase Article III's standing requirements by statutorily granting the right to sue to a plaintiff who would not otherwise have standing." 181 In particular, the Court explained that Congress could not provide standing for a "bare procedural violation" or a deprivation that is not sufficiently "concrete." 182 Whatever these phrases mean, the Court emphatically rejected the claim that "a plaintiff automatically satisfies the injury-in-fact requirement whenever a statute grants a person a statutory right and purports to authorize that person to sue to vindicate that right." 183

Prior to the final decision, the Chamber of Commerce as amicus curiae argued that suits like Robins's must be barred in

178 Robins v. Spokeo, Inc., No. CV10-05306 ODW (AGRx), 2011 WL 11562151, at*1 (C.D. Cal. Sept. 19, 2011).

179 Spokeo, Inc. v. Robins, 135 S. Ct. 1892 (Apr. 27, 2015) (mem.). An impressive array of amici joined Spokeo seeking reversal. Amicus briefs were filed by inter alia the Chamber of Commerce, Pacific Legal Foundation, Washington Legal Foundation, Trans Union LLC, National Association of Home Builders, Ebay Inc., Facebook, Inc., Google Inc., IAC/InterActiveCorp, LinkedIn Corp., Netflix, Inc., Twitter, Inc., Yahoo! Inc., various media organizations (including Time Inc. and National Public Radio Inc.), and eight states (Alabama, Colorado, Michigan, Nebraska, Tennessee, West Virginia, Wisconsin, and Wyoming).

180 Spokeo, Inc. v. Robins, 136 S. Ct. 1540, 1545 (2016).

181 Id. at 1547-48 (quoting Raines v. Byrd, 521 U. S. 811 , 820 n.3 (1997)). See also id. ("In no event . . . may Congress abrogate the Art. III minima") (alteration in original) (quoting Gladstone, Realtors v. Village of Bellwood, 441 U.S. 91, 100 (1979)).

182 Id. at $1549-50$.

183 Id. at 1549. The Court seems more willing to find Congress-created standing when a state is bringing suit. See Massachusetts v. EPA, 549 U.S. 497 (2007); see also Richard H. Fallon, Jr., The Fragmentation of Standing, 93 TEX. L. REV. 1061 (2015). As noted above, the Supreme Court may refine the Spokeo holding further in any number of Article III cases post-Spokeo. See supra note 23 (collecting cases). 
order to avoid a flood of "abusive class-action litigation."184 Technology firms like Facebook and Google asked the Supreme Court to dismiss Robins's suit in order to stem the tide of "noinjury suits" and "in terrorem settlements" arising from a range of federal statutes. ${ }^{185}$ But a dismissal of Robins's suit on Article III grounds cannot have these effects. An Article III dismissal only bars such suits in Article III courts. ${ }^{186}$ Even under the statute as written, FCRA cases may be brought in state courts. ${ }^{187}$ The statute also authorizes administrative proceedings in the Federal Trade Commission (FTC), ${ }^{188}$ and those proceedings typically permit intervention by private parties. ${ }^{189}$

Looking forward, a dismissal in Spokeo would be exactly the type of dismissal-as-invitation that this Article imagines. Suppose that the Supreme Court concluded that plaintiffs like Robins cannot pursue statutory damages under the FCRA if they do not plead actual damages. Congress could amend the statute to provide explicitly for a stand-alone administrative remedy in the FTC or in a new tribunal. This delegation would not humble the federal courts because Robins could not have sued in federal court in the first place. Of course, Congress may not want so-called "no-injury plaintiffs" to sue, and in that circumstance Congress would simply decline the Court's invitation. Admittedly, someone supportive of rigorous FCRA enforcement may chafe at this proposal given Congress's recent

184 Spokeo, Inc. v. Robins, Brief of the Chamber of Commerce of the United States of America, et al., as Amici Curiae in Support of Petitioner, $2015 \mathrm{WL}$ 4148650, at*12-26 (2015).

185 Spokeo, Inc. v. Robins, Brief for Amici Curiae Ebay Inc., Facebook, Inc., Google Inc., IAC/InterActiveCorp, LinkedIn Corp., Netflix, Inc., Twitter, Inc., Yahoo! Inc., The Consumer Electronics Association, Digital Content Next, and The Internet Association in Support of Petitioner, 2015 WL 4148654, at*12-24 (2015) (discussing, inter alia, the Wiretap Act, the Stored Communications Act, the Video Privacy Protection Act, and the Telephone Consumer Protection Act).

These claims were not limited to partisan amici. In a symposium hosted by the Vanderbilt Law Review, every contributor argued that a decision for Spokeo would stop plaintiffs like Robins from vindicating their rights. See Symposium, Balancing as Well as Separating Power: Congress's Authority to Recognize New Legal Rights, 68 VAND. L. REV. EN BANC 181 (2015).

186 Vanderbilt Law Review contributors acknowledged executive branch enforcement of the FCRA, see Elliott, supra note 186, but here I am identifying private enforcement in other forums.

18715 U.S.C. § 1681p (2018) (“An action to enforce any liability created under this subchapter may be brought in any appropriate United States district court, without regard to the amount in controversy, or in any other court of competent jurisdiction ....") (emphasis added).

18815 U.S.C. $§ 1681 \mathrm{~s}(\mathrm{a})(1)$ (2018).

18915 U.S.C. § 45(b) (2018). 
track record, 190 but this approach gives life to the underlying rationale for the Article III dismissal-the separation of powers commands the court to dismiss the case, yet it also allows those separated powers to do something about it. ${ }^{191}$

Another prospective solution looks to the states. ${ }^{192}$ As mentioned above, the FCRA permits enforcement in state courts. ${ }^{193}$ In states that permit standing for such plaintiffs, suits could proceed apace. In states that do not currently permit these suits, state legislatures could accept the Court's invitation. Their response could take the form of a special standing statute for FCRA claims. ${ }^{194}$ Or, they could permit private intervention in state attorneys general actions, which are authorized under the current version of the FCRA. ${ }^{195}$ Again, this approach would not interfere with the federal judicial power, and it could further congressional policy through the states.

The FCRA's state-enforcement provisions also highlight another legislative facet of these issues. When drafting a substantive statute, Congress has the option to declare exclusive federal-court jurisdiction ${ }^{196}$ or (implicitly or explicitly) provide for concurrent state-court jurisdiction. ${ }^{197}$ Indeed, Congress seemingly could provide for exclusive jurisdiction in state courts. ${ }^{198}$ My earlier analysis suggests that Congress's choice

190 See, e.g., Pew Research Center, Drew Desilver, In Late Spurt of Activity, Congress Avoids 'Least Productive' Title (Dec. 29, 2014), http://pewrsr.ch/ ly13OnQ [https://perma.cc/SH2G-JX2G] ("Our calculation finds that the 113th [Congress] just barely avoided the dubious title of 'least productive Congress in modern history."').

191 See supra Part I (exploring separation-of-powers theme).

192 The suggestion here is congenial with, but distinct from, Justice Brennan's suggestion to use state constitutions to protect individual rights. See, e.g., William J. Brennan, Jr., State Constitutions and the Protection of Individual Rights, 90 HARV. L. REV. 489, 495-504 (1977).

193 See supra note 187 and accompanying text.

194 Some states, for example, have special provisions for the enforcement of environmental law. See, e.g., supra note 87 (discussing California's Prop 65).

19515 U.S.C. § $1681 \mathrm{~s}(\mathrm{c})(1)(2018)$.

196 See, e.g., 28 U.S.C. §§ 1333-1334, 1338 (2018); 15 U.S.C. § 78aa (2018).

197 See Tafflin v. Levitt, 493 U.S. 455, 458-59 (1990) (discussing the "deeply rooted presumption in favor of concurrent state court jurisdiction").

198 In Mims $v$. Arrow Financial Services, LLC, the Court entertained but ultimately rejected multiple appellate decisions finding that the Telephone Consumer Protection Act (TCPA) provided for exclusive state court jurisdiction. See 565 U.S. 368, 386-87 (2012) (citing cases and statutory language). Though the Supreme Court rejected this reading, multiple courts approved of it, and the Supreme Court said nothing to suggest that a statute expressly providing exclusive statecourt jurisdiction would be impermissible. Id. Meanwhile, Congress has, in other situations, expressly provided that certain federal-law suits originally filed in state court may not be removed. See 28 U.S.C. § 1445(a) (2018) (limiting removal of Federal Employers' Liability Act claims). 
could be viewed, in part, as a choice about the applicability of Article III's limits. When electing exclusive federal-court jurisdiction, Congress is opting into Article III. But when electing some state-court jurisdiction, Congress is (at least conditionally) opting out of Article III to the extent that states open their courthouses to non-Article III claims. Thus, in these cases, Congress has implied that Article III is not a necessary condition for enforcement, and instead it has invited states to provide for non-Article III resolution.

\section{B. Writ Small: Campbell-Ewald Co. v. Gomez}

"Destined for something big? Do it in the Navy. Get a career. An education. And a chance to serve a greater cause. For a FREE Navy video call [number].”199 On May 11, 2006, Jose Gomez received this unsolicited text message from an automatic dialing service. ${ }^{200}$ It turns out, though, that the Telephone Consumer Protection Act of 1991 prohibits unsolicited automated text messages to cell phones and provides for statutory damages of $\$ 500$ per violation. ${ }^{201}$ Gomez sued on behalf of himself and other recipients of unsolicited texts, seeking to recover hundreds of millions of dollars. Perhaps thinking it had found a way out, the defendant offered Gomez individually more than three times the statutory penalty, and when he refused, it entered an offer of judgment under Federal Rule 68. ${ }^{202}$ Then the defendant filed a motion to dismiss the entire class action as non-justiciable because its offer of complete relief to the named plaintiff rendered the case moot. ${ }^{203}$

The concern with this Rule 68 gambit was that it would allow defendants in class actions to "pick off" named plaintiffs and concomitantly moot claims of unnamed class members. ${ }^{204}$ Were this permitted, the consequences for private enforcement, particularly in cases with large numbers of plaintiffs seeking small-value recovery, could be significant. The Supreme Court ultimately found that the lawsuit was not moot, ${ }^{205}$ but its opinion left the door open to other ways that a defendant could pick

\footnotetext{
199

200

201

202

See Gomez v. Campbell-Ewald Co., 768 F.3d 871, 873 (9th Cir. 2014).

Id.

See 47 U.S.C. § 227(b) (2018).

203 Id.; cf. Genesis Healthcare Corp. v. Symczyk, 569 U.S. 66, 78-79 (2013) (holding that the plaintiff-employee's Fair Labor Standards Act claim was moot after the defendant-employer's offer of judgment in full).

204 See Gomez, 768 F.3d at 875. See also Deposit Guar. Nat'l Bank v. Roper, 445 U.S. 326, 340 (1980).

205 Campbell-Ewald Co. v. Gomez, 136 S. Ct. 663, 674 (2016).
} 
off named plaintiffs. The Chief Justice noted that the Court's holding applies only to offers of settlement, suggesting that the majority's reasoning would not apply to payment of complete relief to a named plaintiff. ${ }^{206}$ Indeed, the holding might not apply to situations exactly like this case except that the defendant deposited the relevant funds with the district court. ${ }^{207}$ Perhaps more ominously, the Chief Justice's opinion made several references to the non-justiciability of disputes where the plaintiff "won't take 'yes' for an answer."208 His opinion also seemingly invited further review of cases in which class-action defendants can avoid litigation by rendering the controversies moot. 209

Under current law or potentially under future decisions led by the Chief, class-action defendants may be able to moot pending cases. However, as with Spokeo, federal and state legislatures are not powerless. Congress could provide for administrative adjudication untethered from the strictures of Article III. Indeed, federal agencies have increasingly turned to class-like mechanisms for dispute resolution, ${ }^{210}$ and Congress could combine those forms with a relaxed mootness requirement to resurrect cases that might have been picked off. Similarly, states could open their courthouses to these class-action suits. ${ }^{211}$ Again, my claim is not that Congress and state legis-

206 Id. at 683 (Roberts, C.J., dissenting).

207 Id. Defendants have tried this technique in a range of cases to mixed success. See, e.g., Fulton Dental, LLC v. Bisco, Inc., 860 F.3d 541, 543 (7th Cir. 2017) (finding the case not moot); Leyse v. Lifetime Ent. Sers., LLC, 679 Fed. App'x. 44, 48 (2d Cir. 2017) (finding the case moot); Conrad v. Boiron, Inc., 869 F.3d 536, 541-42 (7th Cir. 2017) (same). I suspect this is not the last we will hear of this tactic. See, e.g., Petition for Writ of Certiorari, Leyse v. Lifetime Entertainment Services, 2017 WL 3500176 (July 29, 2017).

208 Campbell-Ewald, 136 S. Ct. at 683 (Roberts, C.J., dissenting). The Chief Justice used similar language at oral argument when he said to counsel for Gomez: "[I]f you're getting everything you want, what is the case or controversy? What is the live dispute in which you have a personal stake? . . . You won't take 'yes' for an answer." Transcript of Oral Argument at 30, 36, Campbell-Ewald Co. v. Gomez, 136 S. Ct. (2015) (No. 14-857).

209 Id.; cf. Richard M. Re, Narrowing Supreme Court Precedent from Below, 104 GEO. L.J. 921, 966-71 (2016) (discussing Supreme Court signals).

210 See generally Michael D. Sant'Ambrogio \& Adam S. Zimmerman, The Agency Class Action, 112 ColuM. L. REv. 1992, 2035-48 (2012) (noting examples of agencies using class action-like mechanisms and arguing that agencies should rely on them more).

211 Although a "putative" class action in state court may be subject to removal under the Class Action Fairness Act (CAFA), a finding of no standing should result in remand (not dismissal). See Polo v. Innoventions Int'l, LLC, 833 F.3d 1193 (9th Cir. 2016). If CAFA (or a future CAFA) were understood to bar remand, that result would be consistent with this Article's wider claim regarding legislative authority. 
latures must respond to every Article III dismissal by providing an alternative forum-only that they could do so.

\section{Writ Large: General Statutes}

As noted above, in response to a hypothetical dismissal in Spokeo, Congress could adopt a non-Article III fix for the FCRA. Yet standing problems are broader than one statute. A decision to find no standing in Spokeo (or a case like it) would have consequences for dozens of federal laws. ${ }^{212}$ Environmental statutes have been particular targets of standing dismissals, ${ }^{213}$ and many more statutes rely on private attorneys general for enforcement. ${ }^{214}$

In Schor and again in Wellness International, Justices downplayed the worry that Congress could create "a phalanx of non-Article III tribunals equipped to handle the entire business of the Article III courts . . . ."215 This extreme outcome, the majorities argued, would impermissibly intrude on Article III. But what if Congress created a phalanx of non-Article III tribunals equipped to handle everything but the entire business of the Article III courts? What if Congress adopted a statute that read: "For any statute for which there is a private cause of action, a 'bare procedural violation' is sufficient to authorize a claim in any appropriate federal administrative or legislative tribunal"?216

Generalizing arguments made above, no-standing decisions in federal statutory cases could be seen as an invitation for Congress to pass a general no-standing statute. ${ }^{217}$ Legislating generally, Congress should be able to open administrative

212 See, e.g., Brief of the Chamber of Commerce, supra note 184, at n.3 (collecting statutes).

213 See supra notes 51, 97.

214 See supra note 49 and accompanying text.

215 Commodity Futures Tr. Comm'n v. Schor, 478 U.S. 833, 855 (1986); Wellness Int'l Network, Ltd. v. Sharif, 135 S. Ct. 1932, 1947 (2015).

216 Professor Elliott seems to suggest that the answer is yes in theory, but no in practice, because constraining such a tribunal's jurisdiction to cases outside of Article III is untenable. See Elliott, supra note 26, at 222-24. Here I part company with Professor Elliott. Although I agree that defining the boundary line for non-Article III disputes may not be easy, it is (by definition) symmetrical to defining the boundary line for Article III disputes in federal court. For better or worse, the law of Article III is given. In addition, presumably any such scheme will afford some opportunity - in direct appeal or collateral attack-to challenge the jurisdiction of the first tribunal or to resist an attempt to enforce its judgments.

217 One might say that Congress would not need a real or threatened nostanding decision to create such a statute, but of course it is only through judicial elaboration that terms such as "case or controversy" and "judicial power" acquire useful meaning. 
or legislative tribunals to all cases for which parties lack Article III standing-subject to other constitutional limits. ${ }^{218}$ More likely, Congress could create some new form of standing doctrine, broader than Article III, that would permit more capacious private enforcement of federal law. Either way, the new statute could rely on existing tribunals or create a new default tribunal that could handle all claims for which there is not a specialized vehicle. ${ }^{219}$

Independent of any federal statutory response, states also could respond to the federal courts' invitations with general lawmaking. ${ }^{20}$ A state legislature could pass a statute expressly providing for standing when there is a federal claim but no federal standing. This step would be only somewhat unusual. In many states, the violation of a federal statute that lacks a private cause of action constitutes negligence per se, ${ }^{221}$ and in many areas of law, states create statutory causes of action that build on federal standards. ${ }^{222}$ Here, states would adopt a statute providing for jurisdiction when there is a federal cause of action but no federal-court jurisdiction. Again, a more likely response would provide marginally broader standing than federal courts, but that margin could be important.

To repeat, I am not saying that Congress or the states should take these steps, and I certainly am not predicting that they will. The point is that they can-and any fair evaluation of legislative performance should account for the full range of

\section{See supra Part II.}

219 For an example of a federal tribunal with varied jurisdiction, note that the Court of Federal Claims is an Article I court with jurisdiction encompassing contract cases, takings claims, tribal claims, and cases from numerous federal programs. See generally, Symposium, 71 GEO. WASH. L. REV. 4 \& 5 (2003) (discussing the Court of Federal Claims).

220 As opposed to non-Article III federal tribunals, these state responses would avoid the concerns raised by Professor Elliott, supra note 26, as well as those sounding in "supervisory" requirements. See Pfander, supra note 72, at 653.

221 See, e.g., Grable \& Sons Metal Prods., Inc. v. Darue Eng'g \& Mfg., 545 U.S. 308, 318 (2005) ("The violation of federal statutes and regulations is commonly given negligence per se effect in state tort proceedings.").

222 See, e.g., Moore v. Chesapeake \& Ohio Ry., 291 U.S. 205, 212-16 (1934) (holding that Kentucky's state statute built upon the Federal Safety Appliance Act); Ronald J. Greene, Hybrid State Law in the Federal Courts, 83 HARV. L. REV. 289, 297-305 (1969) (describing situations in which state law incorporates federal rights, obligations, or standards); Martin H. Redish, Supreme Court Review of State Court "Federal" Decisions: A Study in Interactive Federalism, 19 GA. L. REV. 861, 899-09 (1985) (describing situations where states created causes of action built on federal standards). See generally Kevin M. Clermont, Degrees of Deference: Applying vs. Adopting Another Sovereign's Law, 103 CORNELL L. REV. 243 (2017) (systematizing the distinction between applying and adopting another state's laws). 
potential interventions. ${ }^{223}$ At the same time, to the extent that Justices consider the dynamic consequences of their rulings, this thesis might be a self-corrective on aggressive uses of justiciability dismissals.

\section{Connections and Consequences}

Whether legislative solutions are writ small or writ large, they have important connections with the aforementioned literatures on private enforcement and "new new federalism."

With respect to private enforcement, Sean Farhang has found that private enforcement is a particularly popular legislative strategy when Congress is pro-enforcement and the executive is not. ${ }^{24}$ In the modern American political system, this describes a Democratic Congress seeking more vigorous enforcement in the face of a Republican executive branch that Congress does not trust to carry out its preferences. If future elections again produced this alignment, the Democratic Congress could pass a "no-standing" bill in order to lock-in its preferences with respect to enforcement.

Burbank and Farhang also found that the Supreme Court, rather than Congress or the Executive, has been the most forceful contributor to a retrenchment in private enforcement. ${ }^{225}$ The no-standing statute has bite on this dimension as well, as it cuts back on the Supreme Court's ability to restrain private enforcement based on Article III. ${ }^{226}$ Indeed, cases not subject to federal-court jurisdiction are also insulated from federal procedural decisions-think Twombly and Iqbal or Wal-Mart $v$. Dukes ${ }^{227}$ - that do not apply to state courts or administrative agencies. ${ }^{228}$

Turning to states, a reader might wonder why a state would confer jurisdiction for no-standing federal-law claims when the state could simply create a state-law cause of action instead. ${ }^{229}$ One reason would be to insure against preemption. Any state

223 To put it more bluntly, a legislature complaining that the courts are using Article III to interfere with important legislative priorities may have only itself to blame.

224 FARHANG, supra note 49.

225 See BURBANK \& FARHANG, supra note 49, at 1568-80.

226 See supra notes 218-19 and accompanying text.

227 Wal-Mart Stores, Inc. v. Dukes, 564 U.S. 338 (2011); Ashcroft v. Iqbal, 556 U.S. 662 (2009); Bell Atl. Corp. v. Twombly, 550 U.S. 544 (2007).

228 See Clopton, Procedural Retrenchment, supra note 81, at 23 (discussing state courts deviating from federal procedural decisions).

229 I am assuming that the federal statute creates a cause of action, and the limitations in federal court arise from Article III. If the federal statute provided for administrative resolution only, then it might preempt state-court adjudication. 
law in a field of federal regulation is a potential candidate for preemption, ${ }^{230}$ which in turn makes it subject to the Supreme Court's whim. ${ }^{231}$ A state electing to allow federal-law suits would mean that there is no state substantive law to preempt.

Relying on federal law also avoids many challenges arising from the supposed extraterritorial application of state law. ${ }^{232}$ While state laws reaching outside state borders may raise questions for due process, full faith and credit, or the dormant Commerce Clause, ${ }^{233}$ applying federal laws should create no such problems. ${ }^{234}$

Yet another explanation for this outcome relates to Congress's role as a focal point. ${ }^{235}$ Particularly when choosing among regulatory standards that seem equally valid, Congress's selection of any particular standard might create a focal point for regulatory activity. This focal point could apply in federal court, state court, and administrative review, and it could apply to private and public enforcement at both the state and federal levels. ${ }^{236}$ A single focal point reduces transaction costs for regulatees, who would prefer to follow a uniform standard. A focal point also permits formal or informal coordination among various regulatory agents: public and private enforcers, for example, can work complementarily to enforce the same federal standard in multiple forums. ${ }^{237}$

This arrangement also suggests an intertemporal parallel to Farhang's political story. As noted above, Farhang suggests

230 By mentioning a "field" I do not mean to limit this analysis to field preemption-once a federal law appears in a field, it could expressly preempt, create a conflict, or occupy the field. See, e.g., HART \& WECHSLER, supra note 52, at 677-85 (discussing the various ways that federal law may preempt state law).

231 Indeed, the Roberts Court has at times been aggressive in preempting state law. See, e.g., Brooke D. Coleman, Civil-izing Federalism, 89 Tul. L. REV. 307 (2014).

232 See, e.g., Allan Erbsen, Horizontal Federalism, 93 MinN. L. REv. 493 (2008); Katherine Florey, State Courts, State Territory, State Power: Reflections on the Extraterritoriality Principle in Choice of Law and Legislation, 84 NOTRE DAME L. REV. 1057 (2009); Heather K. Gerken, The Taft Lecture: Living Under Someone Else's Law, 84 U. CIN. L. REV. 377 (2016).

233 See, e.g., Allstate Ins. v. Hague, 449 U.S. 302 (1981) (addressing due process and full faith and credit in horizontal choice of law); Edgar v. MITE Corp., 457 U.S. 624 (1982) (dormant Commerce Clause).

234 Other constitutional limits would still apply. See, e.g., Bristol-Myers Squibb Co. v. Superior Court of Cal., 137 S. Ct. 1773 (2017) (limiting constitutional personal jurisdiction of state courts).

235 See Thomas C. Schelling, The Strategy of Conflict (1963).

236 See, e.g., Clopton, Redundant Enforcement, supra note 49; Margaret H. Lemos, Aggregate Litigation Goes Public: Representative Suits by State Attorneys General, 126 HARV. L. REV. 486 (2012); Margaret H. Lemos, State Enforcement of Federal Law, 86 N.Y.U. L. REV. 698 (2011).

237 See Clopton, Redundant Enforcement, supra note 49, at 312. 
that a pro-enforcement Congress might turn to private enforcement when it is dubious of an anti-enforcement executive. ${ }^{238}$ In addition, a pro-enforcement Congress could see the creation of focal points as insurance against future anti-enforcement federal courts $^{239}$ because these focal points would allow proenforcement states to pick up the slack if the federal courts interfered. ${ }^{240}$

The reliance on states also connects with work by Heather Gerken and others on new new federalism. ${ }^{241}$ By involving the states, Congress is inviting states not only to provide outlets for federal claims, but also to participate in the policy-making dialogue. State choices can influence current and future congressional priorities, and recognition of the importance of state legislation might give states further leverage in the national policy-making process.

Importantly, this is all about legislators: Congress and state legislatures make the major policy decisions, and Article III's case-or-controversy requirement does not tell us anything about what the substantive law should say or who should have primary responsibility for enforcing it.

\section{CONCLUSION}

Article III is a sword and shield. Federal courts use the sword of Article III to knock down attempts by Congress to usurp the judicial power of the United States, while the same federal courts use the shield of Article III to close their doors to suits that are unripe, moot, or brought without standing.

This sword-shield view tells us what to do inside of Article III. When a federal court definitively declares a dispute to be outside of Article III, then the Article III dismissal is neither a sword nor a shield, but a beacon. The dismissal tells Congress to "look here"-this is a dispute that the federal courts cannot hear, and if you want this matter resolved, you are free to use non-Article III means to do so. Such a dismissal also tells state

238 See FARHANG, supra note 49 , at 3.

239 On this point, the future may be sooner than we might have expected. See, e.g., Ronald A. Klain, The One Area Where Trump Has Been Wildly Successful, WASH. POST (July 19, 2017), (https://www.washingtonpost.com/opinions/theone-area-where-trump-has-been-wildly-successful/2017/07/19/5bc5c7ee-6be7 -11e7-b9e2-205be768a7e5_story.html?utm_term=.497ea25eddcf [http://perma .cc/WST-MTKK] (observing that President Trump "is on pace to more than double the number of federal judges nominated by any president in his first year" and that "Trump's picks are astoundingly young").

240 Professor Schapiro suggested a similar federal-state dialogue, though his arguments differ from those presented here. See Schapiro, supra note 8.

241 See supra note 28 (collecting sources). 
legislatures that, should they be inclined to promote enforcement along the same lines, they may open state courthouses to these federal claims.

Contrary to those critics of justiciability who claim it has lost sight of its separation-of-powers purpose, these conclusions suggest that case-or-controversy dismissals have direct separation-of-powers effects through their invitation for legislative action. In response to critics of the federal courts' supposed interference with private enforcement, these conclusions suggest that some of that consternation should be directed at legislators. And in keeping with recent focus on federal-state policymaking, these conclusions suggest that Article III dismissals should join the class of structural elements that undergird federalism as the new nationalism. Indeed, both with respect to private enforcement and federal-state collaboration, these conclusions suggest that Article III dismissals might trigger action outside of the courts-exactly what you might expect a separation-of-powers doctrine to do. 